\title{
Voltage sag compensation using direct converter based DVR by modulating the error signal
}

\author{
S. Abdul Rahman, Estifanos Dagnew \\ University of Gondar, Ethiopia
}

\begin{tabular}{l}
\hline \hline Article Info \\
\hline Article history: \\
Received Dec 1, 2019 \\
Revised Mar 2, 2020 \\
Accepted Mar 23, 2020 \\
\hline
\end{tabular}

\section{Keywords:}

Direct converter

DVR

Modulated error signal

SAG

Series transformer

\begin{abstract}
The aim of this paper is to present a modulation technique to achieve highest voltage sag compensation using direct converter based dynamic voltage restorer (DVR). The DVR topology proposed in this paper, has a direct converter and a series transformer. The direct converter is fabricated using only two bi-directional switches. The DVR is designed to compensate the sag in a phase by taking power from the same phase. The direct converter is connected between the series transformer and the line in which sag compensation is to be achieved. Conventionally, the PWM pulses for the direct converters are produced by comparing the error signal with the carrier signal. The error signal is obtained by comparing the amplitude of voltage in the line with the amplitude of the reference voltage. If the amplitude of the carrier signal is kept constant and the actual amplitude of error signal is used for PWM generation, it is possible to achieve only $22 \%$ of voltage sag compensation. But if the error signal amplitude is modulated according to the amplitude of existing voltage sag in the line, $52 \%$ of the voltage sag can be compensated with the THD less than 5\%. Simulation results are presented for validating the analysis.
\end{abstract}

Copyright $\odot 2020$ Institute of Advanced Engineering and Science. All rights reserved.

\section{Corresponding Author:}

S. Abdul Rahman, University of Gondar, Ethiopia.

Email: msajce.abdulrahman@gmail.com

\section{INTRODUCTION}

Though we have many power quality issues like voltage sag, voltage swell, flicker, harmonics, voltage sag is considered to be the severe issue as it affects the operation of sensitive loads like computer, micro controller, Digital Signal Processor, FPGA. As most of the industries are automated, the entire operation of the industries depends upon the operating condition of these sensitive loads. When sag or swell occurs in the industrial areas, these sensitive loads are getting affected, leading to immoral operation of the entire industry [1-8]. For the compensation of voltage sag, Dynamic Voltage Restorer (DVR) considered to be an effective device when compared to other devices like UPS, STATCOM [9-11]. The basic operation of DVR is to inject a voltage in series with the line voltage to mitigate power quality issues. Though many DVR topologies like DVR based on energy storage devices (like batteries, capacitors and super capacitors) have been proposed [12-16], in this paper DVR based on direct convert is presented [17-21]. The compensating range of the DVRs based on energy storage devices, depends upon the rating of the energy storage devices. But in the DVRs based on direct converters, it is based on the availability of voltage in the phase from which the power is taken for compensation and modulating techniques. Only a limited number of papers are available in the literature review for the DVRs based on direct converters. To begin with, the topology presented in [22] based on a matrix converter can mitigate only $25 \%$ of sag and 3 switches are to be modulated during compensation, making the generation of switching pulses somewhat complicated. The zero energy sag corrector without capacitors proposed in [23] can compensate $96 \%$ of voltage sags with 10 numbers of switches. 
Yet another DVR based on an indirect matrix converter developed in [24] can compensate balanced voltage sags of $60 \%$, but it needs a fly wheel energy storage systems with 4 switches. A computation intensive procedure, which runs throughout the cycle, has been described in [25] with 5 bidirectional switches. In spite of these, the compensation range for voltage sag is only 33\%. Even though the topologies described in [26-29], can mitigate 50\% sag, the generation of the switching pulses for the DVR is a bit complicated since 3 switches are to be modulated during compensation.

From the above literature survey it could be observed that to mitigate voltage sag either the topologies have more number of switches or more complicated procedures to mitigate voltage sag. In the proposed topology, only two bidirectional switches are used. In order to mitigate the sag, the error signal is obtained by comparing the peak value of the line voltage with the peak value of the reference voltage. Conventionally this actual error signal is compared with the carrier signal to generate PWM pulses for the direct converter to synthesis compensating voltage. This compensating voltage will be added to the line through the series transformer in order to mitigate the voltage sag. It is been shown in this paper that, if the actual error signal is used to generate PWM pulses, then it is possible to achieve only $22 \%$ of sag compensation. So in this paper, the amplitude of the error signal is modulated according to the percentage of existing sag, and voltage sag compensation of $52 \%$ is achieved.

\section{PRINCIPLE OF OPERATION}

The topology of the direct converter based DVR is shown in the Figure 1. It has a direct converter, a LC filters at the input side of the direct converter and another LC filter at the output side of the direct converter, and a series transformer. The LC filters are used to minimize the harmonics due to switching. The direct converter has two bidirectional switches S1 and S2 as shown in the Figure 1. The topology of the bidirectional switch is shown in the Figure 2.

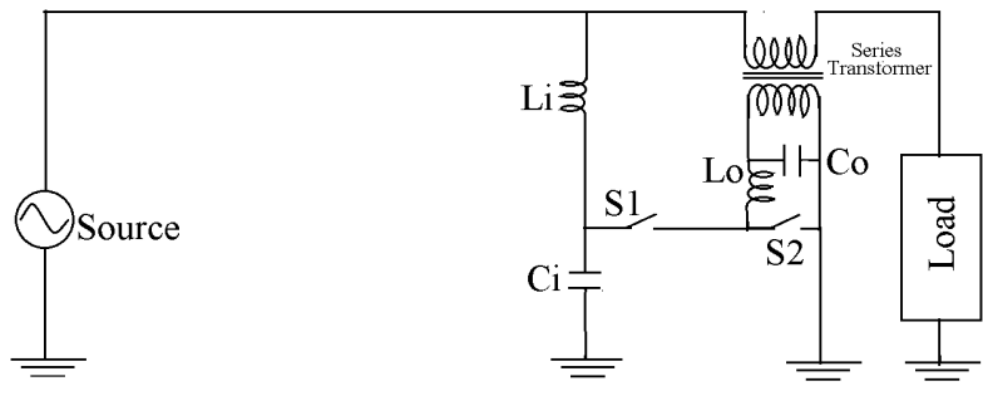

Figure 1. Topology of the DVR

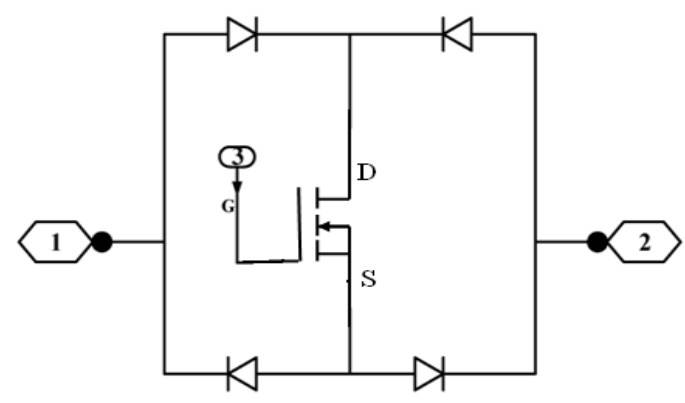

Figure 2. Topology of the bidirectional switch

When the supply voltage is at rated value, the switch S1 is open and switch S2 is closed. In this condition, the secondary of the series transformer is short circuited which results in zero voltage injection and the load voltage is maintained at its rated value. When the sag occurs, the DVR will synthesis the compensating voltage by taking power from the same phase and operating the switches S1 and S2 alternatively. The compensating voltage is added in phase with the supply voltage through the series transformer. The turns ratio of the series transformer is $1: 1$. 


\section{CONTROL ALGORITHM}

Conventional method of generating the PWM pulses for the DVR is shown in the Figure 3. Uref is the peak value of the reference voltage and Ugmax is the peak value of the supply voltage. The supply side voltage is measured and the peak value of the instantaneous voltage is calculated by single phase dq theory [30]. It is compared with the peak value of the reference voltage to generate the error signal. The error signal is compared with the carrier to generate PWM for controlling the switches as shown in the Figure 3.

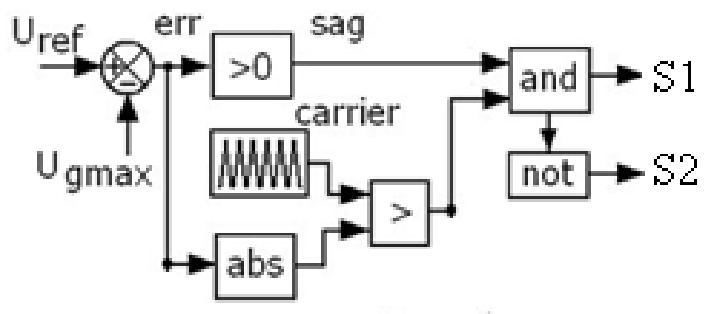

Figure 3. Conventional PWM generation to mitigate sag

In order to generate the PWM, the amplitude of the carrier is signal is kept at 1 unit. The actual error signal in per unit is compared with the carrier signal. As per the IEEE standard the load voltage should be maintained with in the limit of $\pm 5 \%$ of the rated value. It is been observed from the Table 1 that in the conventional PWM generation technique, it is possible to achieve only $22 \%$ of sag compensation since the actual error signal is used to generate the switching pulses. When the sag is more than $22 \%$, for example when the sag is $24 \%$, the supply voltage is $76 \%$ of the rated value. For this $24 \%$ of sag, the PWM on time is only $24 \%$. The compensating voltage synthesized by the direct converter is $24 \%$ of this $76 \%$, which is $18.24 \%$ only. By adding this compensating voltage in the line through the series transformer, the load voltage will be $94.24 \%$ which is not at par with IEEE standard. This is explained in the Table 1 . The same is the case with $40 \%, 50 \%$ and in general, for more than $22 \%$ of sag as proved in Table 1.

Table 1. Possible compensation without modulating the error signal

\begin{tabular}{|c|c|c|c|c|c|}
\hline $\begin{array}{c}\text { Supply Voltage } \\
\text { in } \\
\text { Volts }\end{array}$ & $\begin{array}{c}\% \text { of } \\
\text { Sag }\end{array}$ & Error & $\begin{array}{c}\text { Duty } \\
\text { Cycle of } \\
\text { PWM in } \\
\%\end{array}$ & $\begin{array}{c}\text { Compensating voltage } \\
\text { generated by the DVR = } \\
\text { Supply Voltage * Duty } \\
\text { Cycle }\end{array}$ & $\begin{array}{c}\text { Load Voltage } \\
= \\
\text { Supply Voltage } \\
+ \\
\text { Compensating Voltage }\end{array}$ \\
\hline 100 & 0 & 0 & 0 & 0 & 100 \\
\hline 98 & 2 & 2 & 2 & 1.96 & 99.96 \\
\hline 96 & 4 & 4 & 4 & 3.84 & 99.84 \\
\hline 94 & 6 & 6 & 6 & 5.64 & 99.64 \\
\hline 92 & 8 & 8 & 8 & 7.36 & 99.36 \\
\hline 90 & 10 & 10 & 10 & 9 & 99 \\
\hline 88 & 12 & 12 & 12 & 10.56 & 98.56 \\
\hline 86 & 14 & 14 & 14 & 12.04 & 98.04 \\
\hline 84 & 16 & 16 & 16 & 13.44 & 97.44 \\
\hline 82 & 18 & 18 & 18 & 14.76 & 96.76 \\
\hline 80 & 20 & 20 & 20 & 16 & 96 \\
\hline 78 & 22 & 22 & 22 & 17.16 & 95.16 \\
\hline 76 & 24 & 24 & 24 & 18.24 & 94.24 \\
\hline 74 & 26 & 26 & 26 & 19.24 & 93.24 \\
\hline 72 & 28 & 28 & 28 & 20.16 & 92.16 \\
\hline 70 & 30 & 30 & 30 & 21 & 91 \\
\hline 68 & 32 & 32 & 32 & 21.76 & 89.76 \\
\hline 66 & 34 & 34 & 34 & 22.44 & 88.44 \\
\hline 64 & 36 & 36 & 36 & 23.04 & 87.04 \\
\hline 62 & 38 & 38 & 38 & 23.56 & 85.56 \\
\hline 60 & 40 & 40 & 40 & 24 & 84 \\
\hline 58 & 42 & 42 & 42 & 24.36 & 82.36 \\
\hline 56 & 44 & 44 & 44 & 24.64 & 80.64 \\
\hline 54 & 46 & 46 & 46 & 24.84 & 78.84 \\
\hline 52 & 48 & 48 & 48 & 24.96 & 76.96 \\
\hline
\end{tabular}


But it is possible to improve the range of sag compensation, as sufficient voltage is available at the supply side. It could be observed from the Table 1 that, for a sag of $22 \%$, the duty cycle of the PWM is only $22 \%$ but the available voltage is $78 \%$. Likewise for voltage sag of $30 \%, 40 \%$ and even for $52 \%$, the available voltage at the supply side is $70 \%, 40 \%$ and $48 \%$ respectively. With this much available voltage at the supply side, it is possible to maintain the load voltage within the IEEE standard, by increasing the duty cycle of the PWM. But the duty cycle has to be modulated according to the percentage of available sag. The error signal is not modulated, if the sag is 0 to $22 \%$. The actual error is compared with the carrier to generate the PWM to control the switches. From the Table 1, it could be observed that up to $22 \%$ of sag, the load voltage is maintained at $95.16 \%$ of rated value. If the sag increases beyond $22 \%$, then using the actual error signal the sag can't be compensated as shown in the Table 1. So for the sag of more than 22\%, the error signal is modulated according to the percentage of sag. For a sag of more than $22 \%$ and less than or equal to $32 \%$, the error signal is amplitude modulated for a gain of 1.25 as shown in Table 2, such that the on time of the PWM is also increased by $25 \%$ compared to its original on time. Due to increase in the on time of PWM pulses, the load voltage is maintained at the minimum of $95.2 \%$ of its rated value. It could be observed from Table 2 that if the error signal is modulated by the same gain of 1.25, then the sag can't be compensated beyond $32 \%$, since the load voltage is less than $95 \%$ of rated value. So if the sag is more than $32 \%$ and less than or equal to $41 \%$, the error is modulated by the gain of 1.5 , in order to keep the load voltage to a minimum value of $95.3 \%$ as shown in the Table 3. The block diagram for PWM generation with modulated error signal si shown in the Figure 4.

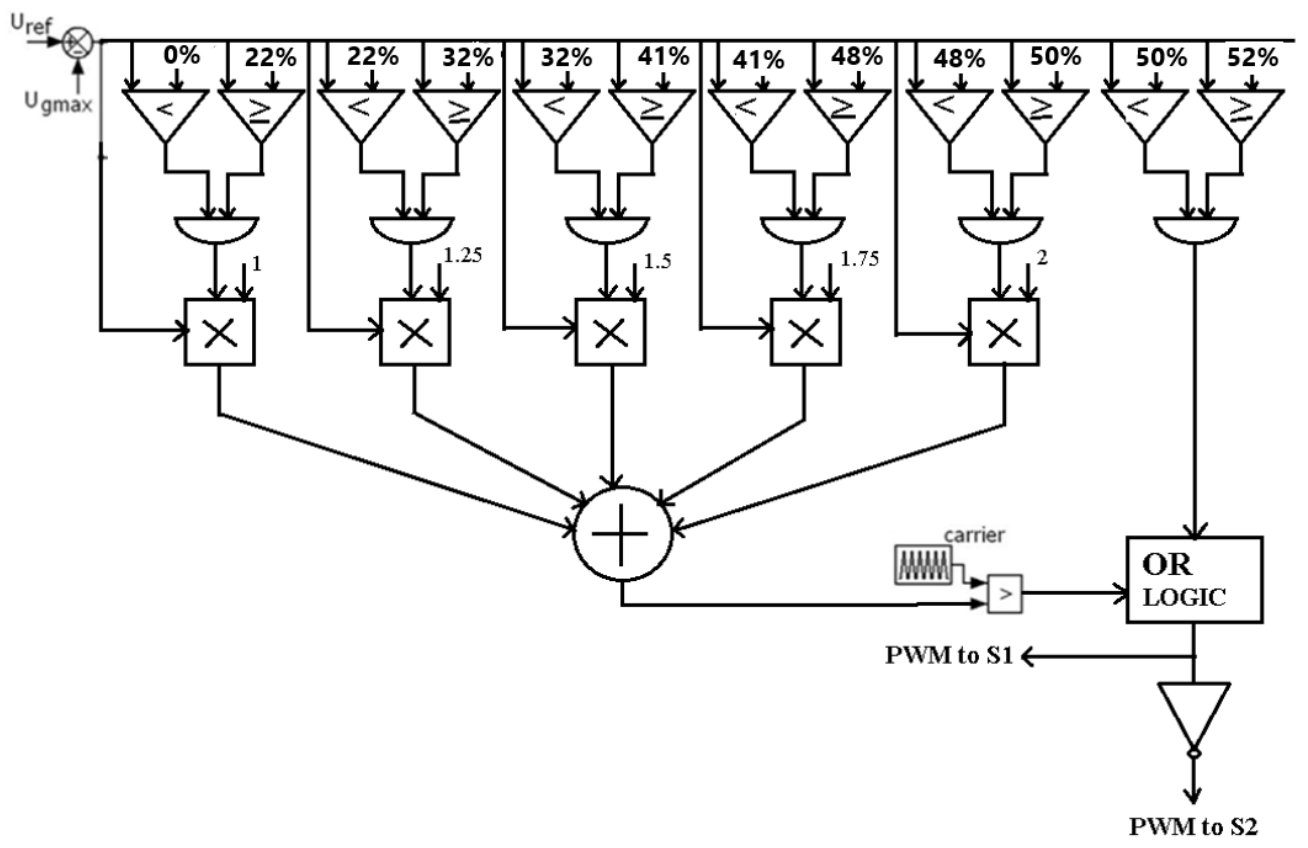

Figure 4. Block diagram for PWM generation with modulated error signal

Table 2. Possible compensation by modulating the error signal by a gain of 1.25

\begin{tabular}{cccccccc}
\hline $\begin{array}{c}\text { Supply } \\
\text { Voltage in } \\
\text { Volts }\end{array}$ & $\begin{array}{c}\text { \% of } \\
\text { Sag }\end{array}$ & Error & $\begin{array}{c}\text { Duty Cycle } \\
\text { of PWM } \\
\text { without } \\
\text { Modulation }\end{array}$ & $\begin{array}{c}\text { Modulated } \\
\text { Error } \\
1.25 * \\
\text { error }\end{array}$ & $\begin{array}{c}\text { Modulated } \\
\text { PWM }\end{array}$ & $\begin{array}{c}\text { Compensating voltage } \\
\text { generated by the DVR } \\
\text { = Supply Voltage * } \\
\text { Modulated Duty Cycle }\end{array}$ & $\begin{array}{c}\text { Load Voltage }= \\
\text { Vompensating } \\
\text { Voltage + Supply } \\
\text { Voltage }\end{array}$ \\
\hline 77 & 23 & 23 & 23 & 28.75 & 28.75 & 22.1375 & 99.1375 \\
76 & 24 & 24 & 24 & 30 & 30 & 22.8 & 98.8 \\
75 & 25 & 25 & 25 & 31.25 & 31.25 & 23.4375 & 98.4375 \\
74 & 26 & 26 & 26 & 32.5 & 32.5 & 24.05 & 98.05 \\
73 & 27 & 27 & 27 & 33.75 & 33.75 & 24.6375 & 97.6375 \\
72 & 28 & 28 & 28 & 35 & 35 & 25.2 & 97.2 \\
71 & 29 & 29 & 29 & 36.25 & 36.25 & 25.7375 & 96.7375 \\
70 & 30 & 30 & 30 & 37.5 & 37.5 & 26.25 & 96.25 \\
69 & 31 & 31 & 31 & 38.75 & 38.75 & 26.7375 & 95.7375 \\
68 & 32 & 32 & 32 & 40 & 40 & 27.2 & 95.2 \\
$\mathbf{6 7}$ & $\mathbf{3 3}$ & $\mathbf{3 3}$ & $\mathbf{3 3}$ & $\mathbf{4 1 . 2 5}$ & $\mathbf{4 1 . 2 5}$ & $\mathbf{2 7 . 6 3 7 5}$ & $\mathbf{9 4 . 6 3 7 5}$ \\
\hline
\end{tabular}

Voltage sag compensation using direct converter based DVR by modulating the error... (S. Abdul Rahman) 
Table 3. Possible compensation by modulating the error signal by a gain of 1.5

\begin{tabular}{|c|c|c|c|c|c|c|c|}
\hline $\begin{array}{c}\text { Supply } \\
\text { Voltage in } \\
\text { Volts }\end{array}$ & $\%$ of Sag & Error & $\begin{array}{l}\text { Duty Cycle of } \\
\text { PWM without } \\
\text { Modulation }\end{array}$ & $\begin{array}{l}\text { Modulated } \\
\text { Error }=1.5 \\
* \text { error }\end{array}$ & $\begin{array}{l}\text { Modulated } \\
\text { PWM }\end{array}$ & $\begin{array}{c}\text { Compensating voltage } \\
\text { generated by the DVR = } \\
\text { Supply Voltage } * \\
\text { Modulated Duty Cycle }\end{array}$ & $\begin{array}{c}\text { Load Voltage }= \\
\text { compensating } \\
\text { Voltage }+ \text { Supply } \\
\text { Voltage }\end{array}$ \\
\hline 67 & 33 & 33 & 33 & 49.5 & 49.5 & 33.165 & 100.165 \\
\hline 66 & 34 & 34 & 34 & 51 & 51 & 33.66 & 99.66 \\
\hline 65 & 35 & 35 & 35 & 52.5 & 52.5 & 34.125 & 99.125 \\
\hline 64 & 36 & 36 & 36 & 54 & 54 & 34.56 & 98.56 \\
\hline 63 & 37 & 37 & 37 & 55.5 & 55.5 & 34.965 & 97.965 \\
\hline 62 & 38 & 38 & 38 & 57 & 57 & 35.34 & 97.34 \\
\hline 61 & 39 & 39 & 39 & 58.5 & 58.5 & 35.685 & 96.685 \\
\hline 60 & 40 & 40 & 40 & 60 & 60 & 36 & 96 \\
\hline 59 & 41 & 41 & 41 & 61.5 & 61.5 & 36.285 & 95.285 \\
\hline 58 & 42 & 42 & 42 & 63 & 63 & 36.54 & 94.54 \\
\hline
\end{tabular}

For the sag of more than $41 \%$ and less than or equal to $48 \%$, the error is modulated by the gain of 1.75 such that the load voltage is maintained at least at $95.7 \%$ as shown in the Table 4 . For the sag of more than $48 \%$ and less than or equal to $50 \%$, the error is modulated by the gain of 2 such that the load voltage is maintained within the IEEE standard as shown in the Table 5. It could be observed from the Table 2 to Table 5 that the load voltage is maintained within the IEEE standard value by modulating the error signal according to the percentage of available sag. If the sag is more than $50 \%$ and less than or equal to $52 \%$, then the switch S1 is fully on and the switch S2 is off such that even for 52\% sag the load voltage will be maintained at $96 \%$ of rated value.

Table 4. Possible compensation by modulating the error signal by a gain of 1.75

\begin{tabular}{cccccccc}
\hline $\begin{array}{c}\text { Supply } \\
\text { Voltage } \\
\text { in Volts }\end{array}$ & $\begin{array}{c}\% \text { of } \\
\text { Sag }\end{array}$ & Error & $\begin{array}{c}\text { Duty Cycle of } \\
\text { PWM without } \\
\text { Modulation }\end{array}$ & $\begin{array}{c}\text { Modulated } \\
\text { Error }= \\
1.75 * \text { error }\end{array}$ & $\begin{array}{c}\text { Modulated } \\
\text { PWM }\end{array}$ & $\begin{array}{c}\text { Compensating voltage } \\
\text { generated by the DVR } \\
\text { Supply Voltage } * \\
\text { Modulated Duty Cycle }\end{array}$ & $\begin{array}{c}\text { Load Voltage }= \\
\text { compensating } \\
\text { Voltage + Supply } \\
\text { Voltage }\end{array}$ \\
\hline 58 & 42 & 42 & 42 & 73.5 & 73.5 & 42.63 & 100.63 \\
57 & 43 & 43 & 43 & 75.25 & 75.25 & 42.8925 & 99.8925 \\
56 & 44 & 44 & 44 & 77 & 77 & 43.12 & 99.12 \\
55 & 45 & 45 & 45 & 78.75 & 78.75 & 43.3125 & 97.3125 \\
54 & 46 & 46 & 46 & 80.5 & 80.5 & 43.47 & 96.5925 \\
53 & 47 & 47 & 47 & 82.25 & 82.25 & 43.5925 & 95.68 \\
52 & 48 & 48 & 48 & 84 & 84 & 43.68 & 94.7325 \\
51 & 49 & 49 & 49 & 85.75 & 85.75 & 43.7325 & \\
\hline
\end{tabular}

Table 5. Possible compensation by modulating the error signal by a gain of 2

\begin{tabular}{cccccccc}
\hline $\begin{array}{c}\text { Supply } \\
\text { Voltage } \\
\text { in Volts }\end{array}$ & $\begin{array}{c}\text { \% of } \\
\text { Sag }\end{array}$ & Error & $\begin{array}{c}\text { Duty Cycle of } \\
\text { PWM without } \\
\text { Modulation }\end{array}$ & $\begin{array}{c}\text { Modulated } \\
\text { Error } \\
2 * \text { error }\end{array}$ & $\begin{array}{c}\text { Modulated } \\
\text { PWM }\end{array}$ & $\begin{array}{c}\text { Compensating voltage } \\
\text { generated by the DVR } \\
\text { Supply Voltage * } \\
\text { Modulated Duty Cycle }\end{array}$ & $\begin{array}{c}\text { Load Voltage }= \\
\text { compensating } \\
\text { Voltage + Supply } \\
\text { Voltage }\end{array}$ \\
\hline 51 & 49 & 49 & 49 & 98 & 98 & 49.98 & 100.98 \\
50 & 50 & 50 & 50 & 100 & 100 & 50 & 100 \\
49 & 51 & 51 & 51 & 102 & 100 & 49 & 98 \\
48 & 52 & 52 & 52 & 104 & 100 & 48 & 96 \\
\hline
\end{tabular}

\section{SIMULATION RESULTS}

For easy understanding, the rated value of supply voltage is set with the amplitude of $100 \mathrm{~V}, 50 \mathrm{~Hz}$. The DVR operates with the filter inductance of $1 \mathrm{mH}$ and filter capacitance of $15 \mathrm{uF}$ at the carrier frequency of $4 \mathrm{KHz}$. In the Figure 5(a), it could be observed that the supply voltage has a sag of $20 \%$ as the amplitude of the supply voltage is $80 \mathrm{~V}$. Even though the supply voltage has $20 \% \mathrm{sag}$, the load voltage is maintained at the rated voltage of $100 \mathrm{v}$ as shown in the Figure $5(\mathrm{~b})$ and the corresponding compensating voltage synthesized by the DVR is shown in the Figure 5(c).

When the supply voltage is at $60 \mathrm{~V}$ with a sag of $40 \%$ as shown in the Figure $6(\mathrm{a})$, the DVR is compensating the sag and the load voltage is maintained at $100 \mathrm{~V}$ as shown in the Figure $6(\mathrm{~b})$, by generating compensating voltage as shown in the Figure 6(c). In the Figure 7(a), it could be observed that the supply voltage has a sag of $50 \%$ as the amplitude of the supply voltage is $50 \mathrm{~V}$. Even though the supply voltage has $50 \% \mathrm{sag}$, the load voltage is maintained at the rated voltage of $100 \mathrm{v}$ as shown in the Figure $7(\mathrm{~b})$ and the 
corresponding compensating voltage synthesized by the DVR is shown in the Figure 7(c). When the supply voltage is at $48 \mathrm{~V}$ with a sag of $52 \%$ as shown in the Figure 8(a), the DVR is compensating this maximum sag and the load voltage is maintained at $100 \mathrm{~V}$ as shown in the Figure $8(\mathrm{~b})$, by generating compensating voltage as shown in the Figure 8(c).

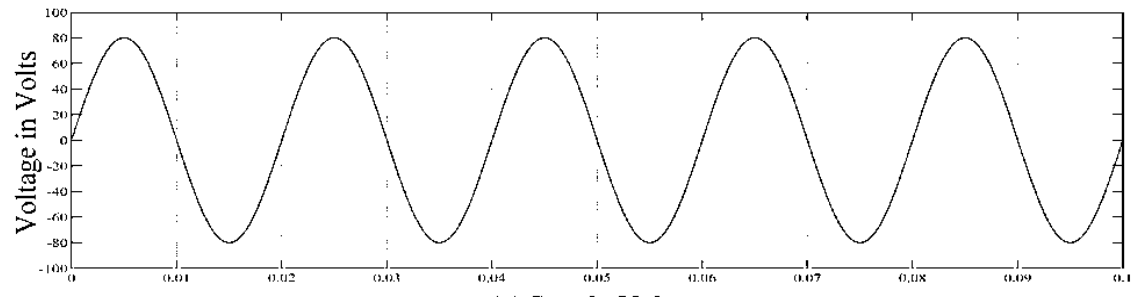

(a) Supply Voltage

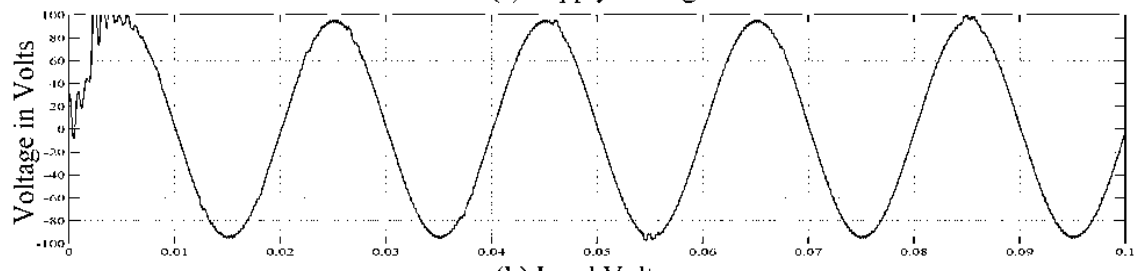

(b) Load Voltage

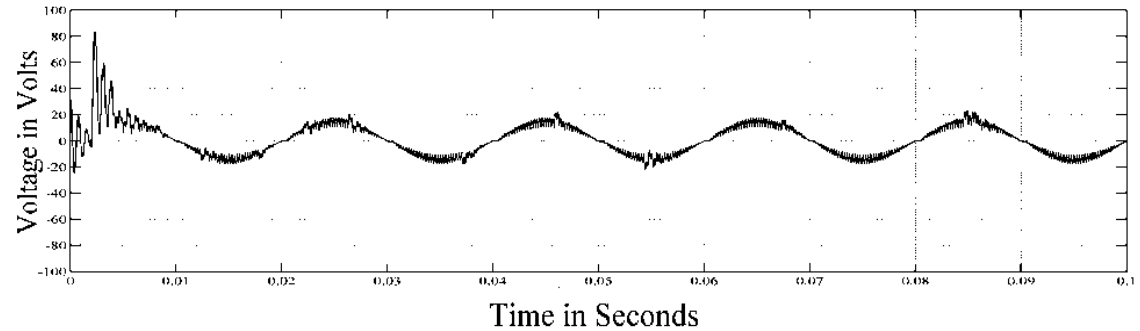

(c) Compensating Voltage Generated by the DVR

Figure 5. Sag Compensation of $20 \%$

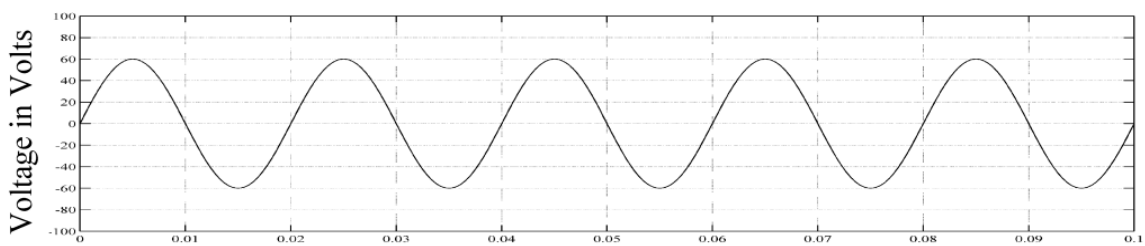

(a) Supply Voltage

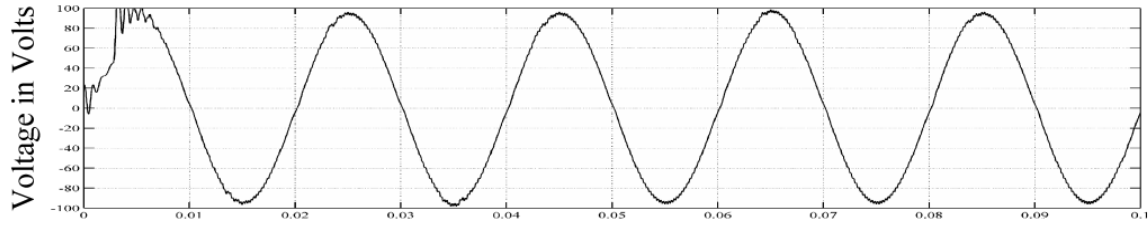

(b) Load Voltage

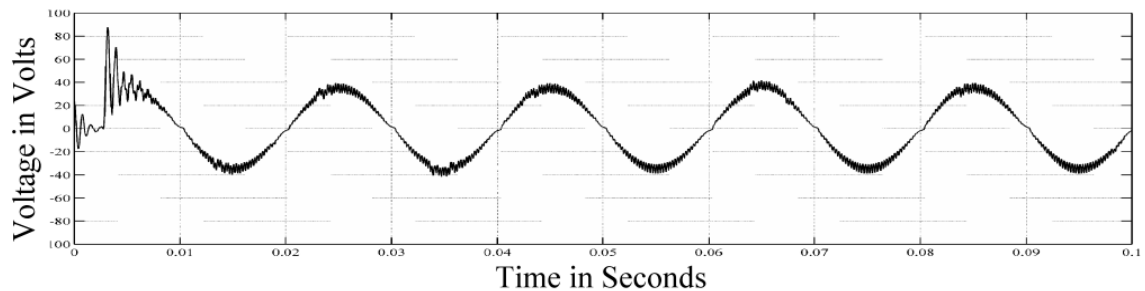

(c) Compensating Voltage Generated by the DVR

Figure 6. Sag Compensation of $40 \%$ 


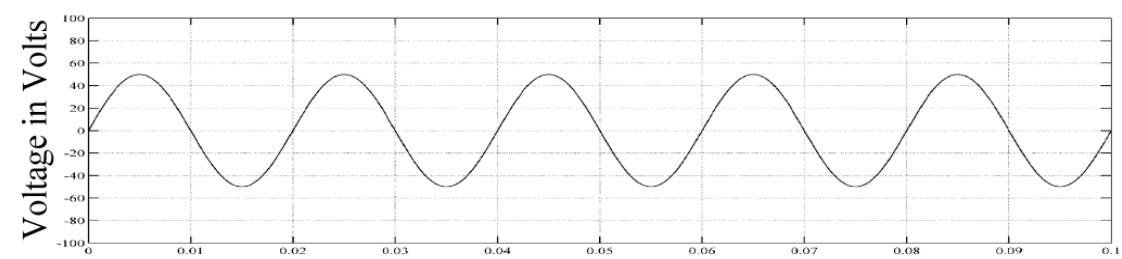

(a) Supply Voltage

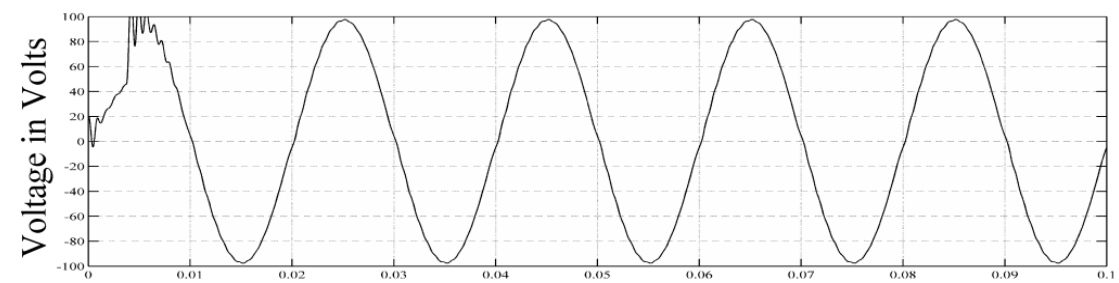

(b) Load Voltage

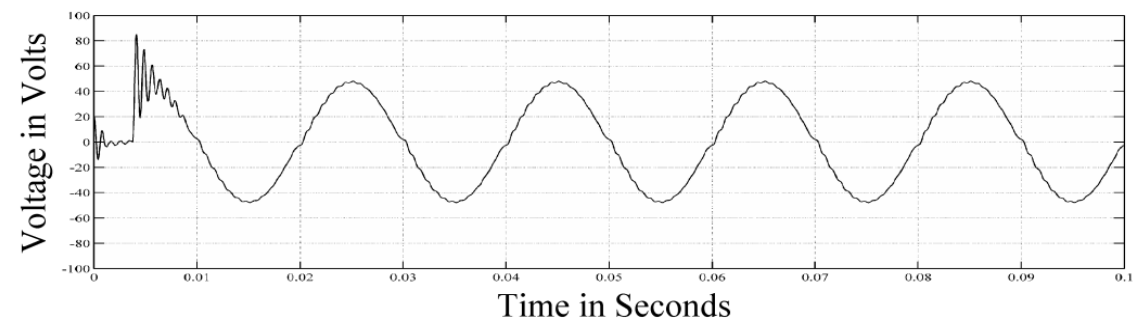

(c) Compenasting Voltage Generated by the DVR

Figure 7. Sag Compensation of $50 \%$

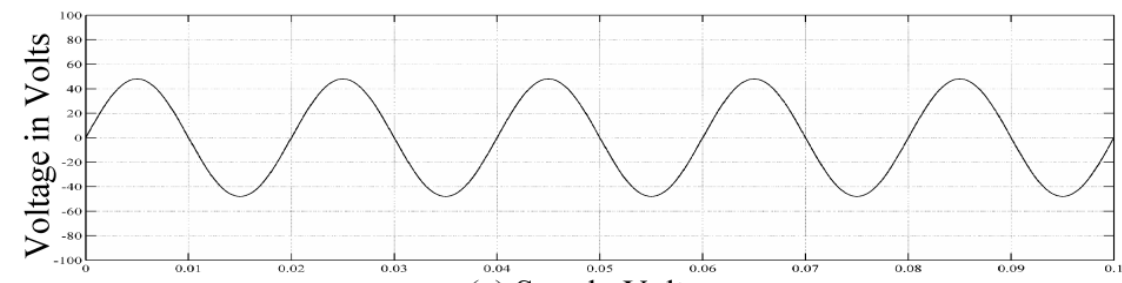

(a) Supply Voltage

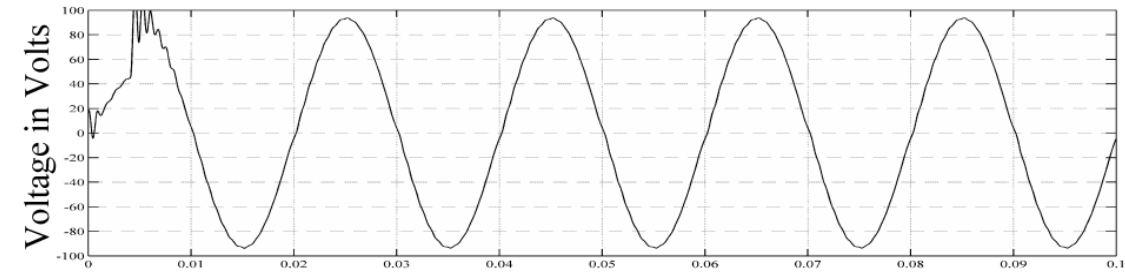

(b) Load Voltage

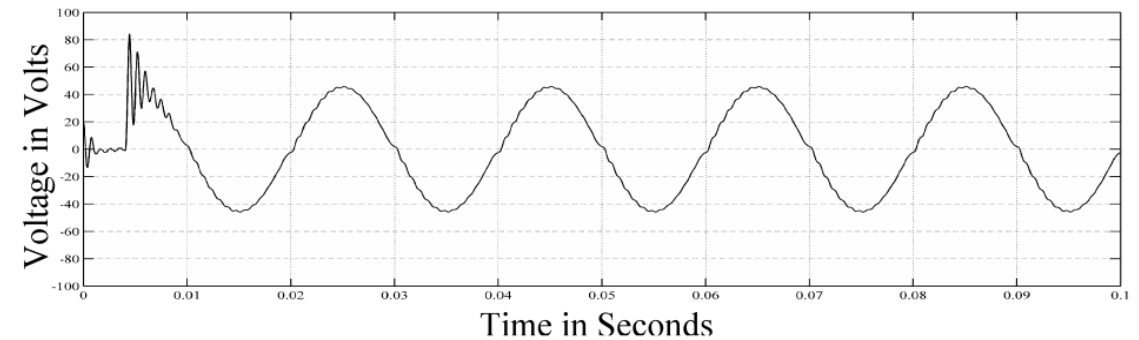

(c) Compensating Voltage Generated by the DVR

Figure 8. Sag Compensation of $52 \%$ 


\section{CONCLUSION}

Though it is possible to mitigate voltage sag using DVR of various topologies, a detailed and easy procedure for obtaining highest sag compensation is not discussed in the literature so far. In this paper highest voltage sag compensation is achieved with the simple topology of DVR based on direct converter and controlled with an easy modulation technique. The DVR topology presented in this paper has got only two bidirectional switches. When the DVR is compensating the voltage as only two switches are operated to mitigate the sag, the switching losses are minimum. The PWM generation is also very easy as these two switches are modulated alternatively. It is been proved in this paper that if the actual error signal is used to generate the PWM for compensating the sag, it is possible to achieve only $22 \%$ of sag compensation. In order to achieve the highest sag compensation, the error signal is amplitude modulated according to the percentage of voltage sag and the PWM is generated according to the modulated error signal. With this modulated error PWM generation, the direct converter based DVR presented in this paper mitigated $52 \%$ of voltage sag with the THD less than $5 \%$.

\section{REFERENCES}

[1] Danalakshmi D, et al., "A control strategy on power quality improvement in consumer side using custom power device” Indonesian Journal of Electrical Engineering and Computer Science (IJEECS), vol 15, no.1, July, 2019.

[2] Ali Basim Mohammed, et al., "Power quality improvement using dynamic voltage restorer in electrical distribution system: an overview," Indonesian Journal of Electrical Engineering And Computer Science (IJEECS), vol 17, no.1, January 2020.

[3] Syed Suraya, P. Sujatha and P. Bharat Kumar, "Contemporary Control of DG Integrated DVR for Sag, Swell and Harmonic Mitigation," International Journal of Electrical and Computer Engineering (IJEECS), vol 8, no 5, October 2018

[4] Weihown Tee, et al, "Voltage Variations Identification using Gabor Transform and Rule-Based Classification Method," International Journal of Electrical and Computer Engineering (IJEECS), vol 10, no 1, February 2020.

[5] Awais Farooqi, et al, "Mitigation of power quality problems using series active filter in a microgrid system," International Journal of Power Electronics and Drive Systems (IJPEDS), vol 10, no 4, December 2019.

[6] N.S. Srivatchan and P. Rangarajan, "Half Cycle Discrete Transformation for Voltage Sag Improvement in an Islanded Microgrid using Dynamic Voltage Restorer," International Journal of Power Electronics and Drive Systems (IJPEDS), vol 9, no 1, March 2018.

[7] K. K. Deepika, J Vijaya Kumar and Gattu Kesava Rao, "Enhancement of voltage regulation using a 7-Level inverter based electric spring with reduced number of switches," International Journal of Power Electronics and Drive Systems (IJPEDS), vol 11, no 2, June 2020.

[8] K. Daud, et al, "Evaluating windowing-based continuous S-transform with neural network classifier for detecting and classifying power quality disturbances," Indonesian Journal of Electrical Engineering and Computer Science (IJEECS), vol 13, no 3, March 2019.

[9] Amirullah Amirullah, Ontoseno Penangsang and Adi Soeprijanto, "Matlab/simulink simulation of unified power quality conditioner-battery energy storage system supplied by PV-wind hybrid using fuzzy logic controller," International Journal of Electrical and Computer Engineering (IJECE), vol 9, no 3, June 2019.

[10] Ahmed Salam Hussein and Majli Nema Hawas, "Power quality analysis based on simulation and MATLAB/Simulink," Indonesian Journal of Electrical Engineering and Computer Science (IJEECS), vol 16, no 3, December 2019.

[11] Ahmed Muthenaa Nori and Turki K. Hassan, "Modeling and simulation of quasi-Z-source indirect matrix converter for permanent magnet synchronous motor drive," International Journal of Power Electronics and Drive Systems (IJPEDS), vol 10, no 2, June 2019.

[12] Jiangfeng Wang, Yan Xing, Hongfei Wu and Tianyu Yang, "A Novel Dual-DC-Port Dynamic Voltage Restorer with Reduced-Rating Integrated DC-DC Converter for Wide-Range Voltage Sag Compensation," IEEE Transactions on Power Electronics, vol. 34, no. 8, 2019.

[13] R. Omar and N. A. Rahim, "Voltage unbalanced compensation using dynamic voltage restorer based on supercapacitor," International Journal of Electrical Power \& Energy Systems (IJPEDS), vol. 43, no. 1, December 2012.

[14] PA Janakiraman, S Abdul Rahman, "Linear pulse width modulation under fluctuating power supply," IEEE Transactions on Industrial Electronics, vol. 61, no 4, pp. 1769-1773, 2013.

[15] S. Abdul Rahman, Gebrie Teshome, "Maximum voltage sag compensation using direct converter by modulating the carrier signal," International Journal of Electrical and Computer Engineering (IJECE), vol. 10, no. 4, 2020.

[16] Toufik Toumi, et al, "PV integrated single-phase dynamic voltage restorer for sag voltage," International Journal of Power Electronics and Drive Systems (IJPEDS), voltage fluctuations and harmonics compensation, vol. 11, no. 1, March 2020.

[17] Suma Jothibasu and Mahesh K. Mishra, "A Control Scheme for Storage less DVR Based on Characterization of Voltage Sags," IEEE Transactions on Power Delivery, vol. 29, no. 5, 2014.

[18] Muhammad Murtadha Othman, et al, "Energy efficiency enhancement using dynamic voltage restorer (DVR)," International Journal of Power Electronics and Drive Systems (IJPEDS), vol 10, no 3, September 2019. 
[19] Deshpande V. Chinmay and Deshpande V. Chaitanya, "Optimum design of dynamic voltage restorer for voltage sag mitigation in distribution network," International Journal of Power Electronics and Drive Systems (IJPEDS), vol 10, no 3, September 2019.

[20] S. Abdul Rahman, P.A. Janakiraman and P. Somasundaram, "Voltage sag and swell mitigation based on modulated Carrier PWM," International Journal of Electrical Power and Energy Systems (IJPEDS), Elsevier, vol. 66, pp. 78-85, 2015.

[21] S. Abdul Rahman and P. Somasundaram, "Voltage sag and swell compensation using AC/AC converters," Australian Journal of Electrical \& Electronics Engineering, vol. 11, no. 2, pp.186-194, 2014.

[22] Abdul Rahman, "Mitigation of Voltage Sag, Swell and Outage without Converter," International Journal of Latest Transactions in Engineering and Science (IJLTES), vol. 8, no. 1, 2019.

[23] Prasai, and D.M. Divan, "Zero-energy sag correctors-Optimizing dynamic voltage restorers for industrial application," IEEE Trans. Ind. Appl., vol. 44, no. 6, pp. 1777-1784, 2008.

[24] Wang, and G. Venkataramanan, "Dynamic voltage restorer utilizing a matrix converter and flywheel energy storage," IEEE Trans. Ind. Appl.,vol. 45, no. 1, pp. 222-231, 2009.

[25] E. Babaei, M.F. Kangarlu, and M. Sabahi, "Mitigation of Voltage Disturbances Using Dynamic Voltage Restorer Based on Direct Converters," IEEE Transactions on Power Delivery, vol. 25, no. 4, pp. 2676-2683, 2010.

[26] S. Abdul rahman, "Direct Converter Based DVR to Mitigate Single Phase Outage, "International Journal of Recent Technology and Engineering (IJRTE)," vol. 8, no.3, pp.85-88, September, 2019.

[27] Abdul Rahman Syed Abuthahir, Somasundaram Periasamy, Janakiraman Panapakkam Arumugam, "Mitigation of Voltage Sag and Swell Using Direct Converters with Minimum Switch Count," Journal of Power Electronics, vol. 14, no. 6, pp. 1314-1321, 2014.

[28] Abdul Rahman, "Mitigation of Single Phase Voltage Sag, Swell and Outage Using Voltage Controlled Voltage Source," Global scientific Journal, vol. 7, no. 10, 2019.

[29] Abdul Rahman, "Realization of Single Phase Matrix Converter Using 4 Controlled Switches," International Journal of Engineering, Applied and Management Sciences Paradigms, vol. 54, no. 7, 2019.

[30] S. Abdul rahman, and P. Somasundaram, "Mitigation of Voltage Sag and Swell Using Dynamic Voltage Restorer without Energy Storage Devices," International Review of Electrical Engineering, vol. 7, vo.4, pp. 4948-4953, 2012. 